\title{
The Historical Regions of Europe: Civilizational Backgrounds and Multiple Routes to Modernity
}

\author{
GERARD DELANTY*
}

Historické regiony Evropy: Civilizační základ a vícečetné cesty $k$ modernitě

\begin{abstract}
A systematic typology or comparative analysis of European historical regions does not exist and there is relatively little literature on the topic. The argument in this paper is that a six-fold classification is needed to capture the diversity of Europe's historical regions and that these should be seen in terms of different routes to modernity and have broad civilizational backgrounds in common. The forms of modernity that constitute Europe as a world historical region correspond to North Western Europe, Mediterranean Europe, Central Europe, East Central Europe, South Eastern Europe, North Eastern Europe.
\end{abstract}

Key words: Modernity, civilizations, Europe, historical regions.

\section{Introduction}

The topic of this paper concerns the problem of conceptualizing the plural nature of Europe. ${ }^{1}$ The civilizational background has itself been diverse with routes within it that were shaped by the western and eastern currents of Roman civilization, the Russian offspring of the Byzantine tradition that developed in the east, and the multifarious impact of Islam on the Iberian and the South Eastern regions. Four inter-linked civilizational currents formed, what I have elsewhere termed, the European inter-civilizational constellation: the Greco-Roman, the Western Christian, the Byzantine-Russian and Ottoman-Islamic traditions [Delanty 2002]..$^{2}$ The unity and diversity of Europe derives from its civilizational diversity, which also established the basis of different traditions of empire. However, this does not offer a sufficient basis for an assessment of the unity and diversity of Europe, for with the unfolding of the project of modernity new dynamics came into play bringing about a more complicated tapestry that cannot be so easily accounted for in terms of civilizational forms alone. Modernity brought about a major transformation in the moral and political horizons of European societies. It placed the individual on a new level and put forward new ideas about political community that gave to the modern world a cultural model that both united and divided it, for the new ideas were not only differently interpreted in terms of their application, but were also differently formulated. Yet, certain trends unfolded that can be said to constitute the basic matrix of a European societal model; moreover, the ideas of modernity, including the idea of Europe, gave to European an imaginary that defined its

\footnotetext{
* Prof. Gerard Delanty. Department of Sociology, University of Sussex, Brighton, BN1 9SN, UK. E-mail: g.delanty@sussex.ac.uk

1 The paper is based on Chapter 10 of my forthcoming book Formations of European Modernity: A Historical and Political Sociology of Europe (Palgrave Macmillan 2013).

2 Arguably a case could be made for the inclusion of Judaism as a separate civilization (in Eisenstadt's terms: a diasporic civilization).
} 
identity. As with the civilizational background, modernity, too, crystallized into different forms and were taken up in different regional routes. The objective of this paper is to examine the regional diversity of Europe as a product both of civilizational backgrounds and the trajectories of modernity. This will entail in part a forward perspective to the twentieth century, since the shape of these routes was altered in the course of that century with the rise and fall of the Soviet Union and the creation and expansion of the European Union. However for reasons of space this cannot be explored in the present paper.

The notion of modernity offers a useful way to view the diversity of Europe since it includes a perspective on both unity and diversity. Modernity is based on a cultural model that provides a general framework of ideas and a cultural orientation; it is also based on a societal model, which can be seen in terms of relations between state, economy and civil society. A feature of European modernity in general was the fact that civil society remained relatively strong. The state was constantly challenged by organized social interests, which often became incorporated into the sphere of the state domesticating both the state and civil society and both exerted a strong influence over the market so that capitalism was constantly held in check by the state. In this view, the varieties of modernity that developed in Europe can be in part understood in terms of the different ways this societal model crystallized in the different historical regions of Europe. The notion of a historical region, despite the problems of definition, offers a fruitful approach to the analysis of the idea of Europe and an alternative to purely national histories.

A broad definition of Europe's historical regions would identify three, namely western, central and eastern Europe, to follow Jeno Szücs [1988] classification in his famous essay "The Three Historical Regions of Europe" in which he argued for three historical regions: Western, East Central and Eastern Europe. In an earlier classic work Oskar Halecki [1950] identified four historical regions: western, west-central, east central and eastern. However, a more differentiated and systematic approach is needed given the especially complicated nature of Central Europe and the post 1989 context that led to a major reconfiguration of central and eastern Europe and the system of states established in 1919. A systematic typology or comparative analysis does not exist and there is relatively little literature on the topic [see Arnason and Doyle 2010]. The proposal in this paper is that a six-fold classification is needed to capture the diversity of routes to modernity without reducing all such routes and models of modernity to national trajectories or collapsing them into more general civilizational categories. The forms of modernity that constitute Europe as a world historical region correspond to North Western Europe, Mediterranean Europe, Central Europe, East Central Europe, South Eastern Europe, North Eastern Europe.

As with all such classifications there is the problem of defining specificity and taking into account overlap as well as broader contexts of commonality. Furthermore there is the complication that historical regions do not remain constant with the result that different configurations may be relevant in different periods. The map of Europe's regions will have been very different from the standpoint of the tenth century or the seventeenth century. However for the purpose of the present analysis assumptions will be made about the longue durée from the perspective of the present. An additional problem is the degree to which self-identification should be taken into account. In the case of historical regions self-identification can be regarded as less important than in defining national identity, not least since regional identity is not the most important feature of a historical region whose specificity 
may be the basis of different but related identities. To add a further level of complication, many regions are the product of ideological constructions - for example the notion of Mitteleuropa, or Eastern Europe or the notion of the Balkans - and can be hegemonic in the ways in which they establish taken for granted relations between peripheries and centres. The more general categories of western, central and eastern, or a dichotomy of West and East also do not offer a sufficiently rich basis on which to explore the variety of models of modernity in Europe.

The case for the specificity of these regions will be made below in more detail. A notion of historical region implies that there is a common historical experience that can be discerned in the longue durée and that common features of the region's history are more significant than the differences [Müller 2010: 114]. The general rationale in this paper for a differentiated approach to Europe's historical regions is, firstly, that each must correspond to a distinctive route to modernity which is a variant of the more general form that European modernity took; secondly, there should be a broad background in civilizational contexts. Together civilizational backgrounds and routes to modernity define the identity of a historical region and give to it a certain unity which in turn is the basis of a "mental map". In short, it is necessary to define the regions as transnational historical spaces in terms of their relation to Europe - as variants of a more general historical space - and in terms of their specificity in relation to each other as areas of close interaction and historical commonality.

A final preliminary observation is that all these historical regions are not self-enclosed enclaves, but overlapping and in many cases their historical experience entailed at different points a shared history, as in the case of those areas that fell under Soviet rule in the post 1945 period. For these reasons, Europe's historical regions might be seen as borderlands. The borders that have shaped the historical regions of Europe changed so many times that they are best seen less as lines of division than as lines that constitute intersecting spaces. For Balibar [2004]. Europe is itself a borderland in that it is made up of multiple spatialities in terms of state formation, markets, social and cultural institutions and identities. In this view, any reference to a geopolitical or historical region must recognise its interconnections with other regions. Europe's regions should thus be seen in terms of hyphenated spatialities than as separated territories. The following discussion of Europe's six major historical regions will consider the interconnected nature of these regions as much as their singularity.

\section{North Western Europe}

The very notion of a North Western Europe is itself an acknowledgement of a borderland. Rather than speak of western Europe in general, it is more meaningful to take the more circumscribed category of North Western Europe. This includes the British Isles, Scandinavia ${ }^{3}$, France, the Low Countries and Germany. As a borderland, the inclusion of Germany ties the area to Central Europe, given the overlapping nature of Germany, which

\footnotetext{
3 There may be an argument for Scandinavia to be considered part of a distinct Nordic region. For present purposes, given the model of modernity that evolved there it is considered part of the wider North Western region [see Arnason and Wittrock 2012].
} 
includes more than one historical region. The region may be extended to include northern Italy and parts of the Iberian Peninsula could arguably claim to be part of a wider notion of western Europe. However, the notion of North Western Europe puts the emphasis on the northernness of the region and for this reason it is best seen in more limited terms as an area that can be located within the broader category of western Europe, but which exhibits distinctively northern features.

North Western Europe has been influenced both by Central Europe in general and more specifically by Mediterranean Europe. In earlier periods, Southern Europe provided the basic civilizational orientations for all of Europe and North Western Europe bears this influence. However, in the course of history the western area of Europe became progressively distinct from Southern Europe and its shared characteristic with the regions of Central and Eastern Europe too became less formative. The Frankish leadership under Charlemagne gave to the region its essential identity, which according to Henri Pirenne [2001] in his famous thesis first published in 1935 - "without Mohammed there would have been no Charlemagne" - was made possible by the rise and advancement of Islam across the southern shores of the Mediterranean.

As we have seen, state formation since the nineteenth century tended to move in the direction of sea-based empires and with a relatively high degree of democratization in the metropole. With its historical basis in the Carolingian kingdom and the area west of the Rhine, the North West region became what has often been called modern or core Europe and formed the basis of what was eventually to become the European Union. However misleading the idea of a core Europe is and despite the many wars fought within the region between the dynastic powers and the later national states, North Western Europe exhibits remarkable similarity in its political, economic and wider societal structures and institutions. It has undeniably played a major role in the shaping of modern Europe both for good and for bad. The diversity of its regions in terms of cultural factors, such as language and national identity, disguises a certain unity that is discernable more in the myriad of interconnections than in a common framework. No such structure developed, at least until the formation of the EEC in 1958; yet, the region has had a relatively common history in terms of both its civilizational background and in its model of modernity. A crucial fact in its uniformity and overall dominance has been the fact that the region enjoyed relative uninterrupted growth and consolidation over several centuries, while the eastern regions underwent major changes in their civilizational directions. The Mongol invasions of Russia, the latter's expansion over eastern and central Europe, and the Ottoman conquests of the South East, the German onslaught in the 1940s led to more turbulent histories.

The civilizational roots of North Western Europe were formed by Latin Christianity and in part by the Roman Empire. However much of the area lay outside the territory of the Roman Empire, which can be considered to have been less important than the state tradition and the institutions that developed in the medieval age. A key aspect of this was the struggle between Church and State and the fact that in the balance that was finally achieved the state retained juridical autonomy and was not subordinated to ecclesiastical authority. The result was a clear separation of state and society. The states that formed in Northern Western Europe have been relatively settled in their basic structures and territories and the nation-states that consolidated there witnessed greater stability and continuity than in most other parts of Europe where the state tradition and nationhood led to less peaceful 
outcomes. Earlier, feudalism established the conditions for economic and political stability as did its relatively early abolition. The "Great Transformation" that led to the emergence of the modern market society that Karl Polanyi [1944] characterized as the basis of modern society was most vividly present in North Western Europe where the industrial revolution and the formation of the modern class structure was also most advanced. In addition to these factors relating to the state formation and market society, North Western Europe had a long tradition of the autonomy of the city vis-à-vis the countryside. The rise of civil society, decisive for the emergence of modernity, was possible only because of the autonomy of the city and the kinds of authority that it cultivated. Later patterns of democratization were built on these foundations.

The societal model of modernity that developed in North Western Europe can thus be characterized as a relatively distinct one whose early crystallization has been important in the overall shaping of Europe. The Cold War and the rise of military and fascist regimes in southern Europe in the post-1945 period gave to it an additional identity based on democracy and capitalism. For instance, Spain, under Franco until 1975, was relatively isolated and experienced a different transition to the European social model in the twentieth century that clearly demarcates it from the experience of North Western Europe. In this region democratic capitalism enjoyed a period of uninterrupted growth since 1945 in contrast to Eastern and Southern Europe, where the democratic tradition was variously interrupted. Italy, at least until the 1980s, was the exception, but there the huge divide between north and south and the power of the Mafia in Italian politics, put it on a different trajectory from Northern Europe. North Western Europe contains the most powerful economies in Europe and in the world, the Germany, UK, France, the latter two having had the largest overseas empires. It can be finally noted that North Western Europe was western in another sense: it was part of the wider West world with its centre in the Atlantic rather than in the Mediterranean or Black Sea. Today, in the twentieth first century, this may have lost much of its force, but in the previous century it gave to the area an identity that consolidated an historical trajectory that might otherwise have had less specificity.

\section{Mediterranean Europe}

The notion of a Mediterranean Europe presents some obvious difficulties since it covers a wider and diverse area stretching from the Iberian peninsula, southern France, Italy, part of the southern Balkans and Greece. As with all of the historical regions of Europe it does not have clear cut boundaries and more or less all of its constitutive countries are not entirely Mediterranean in their entirety. Unlike the other historical regions it is more difficult to specify a historical core area, though arguably that core is Roman. The case of Greece is a complication, since its civilizational background and path to modernity is markedly different from the countries of the western Mediterranean. For this reason it is probably best located as part of South Western Europe. Another complicating case is Portugal, while not having a Mediterranean coast and more Atlanticist in orientation is nonetheless from its civilizational influences clearly not too far removed from the wider Iberian context. Despite these qualifications it is possible to speak of the specificity of a Mediterranean Europe as a historical region. 
This region is above all a civilizational one that was shaped by the Roman Empire and Catholicism. The Roman Empire provided the most enduring cultural and geopolitical framework for the emergence of Europe, but this was primarily a Mediterranean civilization rather than a northern or western one. The cities founded by the Romans as well as the roadways they built gave to the region a matrix that laid the basis of a civilizational orientation. However, the post-Roman empires were all greatly shaped by its legacy as were the national cultures and the modern nation states that emerged in the area. The Holy Roman Empire is one such legacy that for almost a thousand years from the tenth to the eighteenth century gave a certain unity to much of Europe. While this had a pronounced Habsburg dimension since the early sixteenth century, when it became known as the Holy Roman Empire of the German Nation, it was modelled on the memory of Rome. The cultural heritage of the Roman empire is easily discernable along the shores of the Mediterranean in ways of life, language, religion, climate and the built environment. Greece, different in its language and religion from the largely Latin influenced western areas, is equally part of the Southern Eastern historical region; its state tradition is different from the western European one, as its model of church state relations, and the slow development of capitalism marks it off from the wider Mediterranean area.

The Roman origins of Mediterranean Europe draw attention to the wider unity of the Mediterranean and the fact that the Roman Empire was not simply European but included North Africa and parts of the middle east. The Roman Empire was itself shaped by Greek antiquity and by the numerous cultures it encountered. Entailed in this is the idea of a Euro-Arab region, for both the European and the Arab shores of the Mediterranean form part of the wider unity of the region. This was not only in the distant past. Much of the Maghreb was part of Europe in the twentieth century and several wars were played out in the area as a result of the imperialist ambitions of the European powers. Algeria was an integral part of France until after the war of independence in 1962; the circumstances that led to the Spanish civil war emerged from the loss of Spanish dominion in North Africa; fascist Italy sought to control Ethiopia. The notion of a Mediterranean Europe as a historical region is best understood as a borderland region formed out of cross-cultural encounters and the civilizational legacy of Rome. This borderland can be considered the basis of what Ian Chambers [2008] has termed a "heterogeneous modernity" which is a particularly striking feature of the area.

The examples of Malta and Cyprus capture the spirit of Mediterranean Europe as a borderland and one deeply influenced by the Roman origins, as well as the later Byzantine Empire. The two islands had been for long part of the Muslim world. Malta's chequered history was marked by various periods of conquest by the Normans, the Arabs, the Germans, Spanish, British and was the scene of numerous wars. Cyprus is an example of Greek, Greco-Roman, and Ottoman encounters and divisions. Today these islands are part of the EU and constitute the heart of the wider Euro-Mediterranean area, an identity that was revived in the 1990s with the enlargement of the EU.

The idea of a European Mediterranean took on a new form in 1995 with the Euro-Mediterranean partnership between the European Union and the countries of the Southern Mediterranean, and revived in 2008 with the idea of the Union of the Mediterranean, which was created to promote economic integration and democratic reform across sixteen countries in Southern Europe, North Africa and the Middle East (these being Albania, 
Algeria, Bosnia and Herzegovina, Croatia, Egypt, Israel, Jordan, Lebanon, Mauritania, Monaco, Montenegro, Morocco, the Palestinian Authority, Syria, Tunisia and Turkey). The EU has been effective in giving shape to the European Mediterranean as a regional identity [Pace 2004; Featherstone and Kazamias 2001].

In terms of patterns of modernity that developed in the region, Mediterranean Europe, the historical models of modernity associated with France, Italy and Spain can all be considered to be firmly within the wider western Europe tradition, albeit with large variations and uneven development, such as the contrast between southern and northern Italy. The twentieth century fascist and military regimes in Italy, Portugal, Spain, and Greece - and the civil wars within the latter two countries - are a reminder of a weaker state tradition and an interrupted transition to democracy. The case for the distinctiveness of a Mediterranean Europe is largely made on the basis of its civilizational influences. However, considered as a whole the pattern of modernity in terms of state formation, capitalism, and civil society bears the mark of the European societal model in so far as the democratizing influences of civil society are concerned. In all its areas the national state was established by the nineteenth century, a feature it shares with North Western Europe and a contrast to Central and Eastern Europe. For all these reasons the idea of a Mediterranean Europe can be regarded as a distinctive transnational historical region.

\section{Central Europe}

Of all of Europe's historical regions, Central Europe is the one that comes closest to having a regional identity rooted both in civilizational currents and in a model of modernity. ${ }^{4}$ The idea of Mitteleuropa has a long resonance in the German speaking world. Although not an identity as such, it invokes a heritage that is distinct from both eastern and western Europe. Like the term Europe itself, it has always been a contested term and has had different uses depending on when and by whom it has been used. It had pan-German origins, but with the political instrumentalization of the pan-Germanism with the Nazis, it became most widely used as an Austrian nostalgic term for the Europe of the Austro-Hungarian empire. In the 1980s it acquired a more pronounced political meaning in Hungary and Czechoslovakia as a way of defining the European heritage of those countries against the Soviet Union and communism. In this use of the term, as advanced by Milan Kundera and George Konrad, it signified civil society. As a historical region, Central Europe - as opposed to the idea of Mitteleuropa - includes southern Germany, Austria, Switzerland, and much of what will be discussed separately as East Central Europe, namely Poland, the Czech Republic, Slovenia and Slovakia. The historical heart of the region is the area once covered by the Austro-Hungarian empire. Its centres were Vienna, Prague, Ljubljana, Trieste, Bratislava and Budapest and could be extended to parts of South Eastern Europe, certainly Zagreb. In this sense it is a poly-centric historical region.

The idea of Mitteleuropa has been the subject of several influential works that have contributed to the regional identity of the region. The most well known are Friedrich Naumann's Mitteleuropa in 1915, Thomas Masaryk's The New Europe in 1918 and Claudio Magris's Danube [2001]. The geographical and political notion of Mitteleuropa by definition can

4 This section draws in part on Vidmar-Horvat and Delanty [2005]. 
only be a relative term since its definition rests on assumptions on the borders of Europe. In the case of the eastern border, which has been the most important in the self-definition of Mitteleuropa, this has shifted numerous times. As Kundera [1984: 35] has written, "Its borders are imaginary and must be drawn and redrawn with each new historical situation". Obviously, the notion is essentially cultural rather than geopolitical.

The idea of Mitteleuropa had been part of German economic policy since Frederick List promoted it as an area of free trade, but it should not be equated with Prussian expansionism. For Naumann Mitteleuropa referred to the larger German speaking lands as well as the non-German regions of the Habsburg empire, and was as much a political and cultural category as it was economic; Thomas Masaryk, the first president of Czechoslovakia, in contrast, used the term to exclude German and Austria, essentially meaning the smaller countries of East Central Europe (see below). In this view, Mitteleuropa is not located between north and south and could include Greece and Finland. A related idea, influential in Germany in the inter-war years, was the notion of Zwischeneuropa, first coined by the geographer Albrecht Penck in the early twentieth century, and which can be translated as a borderland Europe, though literally meaning "in between" Europe, that is the "in between" areas between East and West. The term was revived in Austrian nationalism to connect the country to the Habsburg past. Any discussion of the notion of Mitteleuropa runs the risk of either polemics or simplification. Like Europe as a whole it lacks clear borders, suggesting it is more like a state of mind or a culture or fate, as Milan Kundera has argued, than a state or territory.

The notion of Mitteleuropa should not be dismissed as nostalgia for the Habsburg empire, Catholicism or as a German expansionist ideology, simply because it had too many meanings, which include a certain cultural cosmopolitanism. In a region where the nation-state developed later than in North Western Europe, there is some value in re-assessing it in light of the region's multi-ethno-nationalism. In addition, there is the relevance of the wider appeal in the region for a supranational ideal. Without this the very possibility of Czechoslovakia or Yugoslavia, as a union of states, or the Dual Monarchy of Austria and Hungary would not have been possible. These now vanished confederal states were a feature of the political landscape of Europe in the mid-twentieth century and their disappearance has not been without a certain loss of opportunity to a create multi-national state. It was this sense of the term that the Austro-Marxists sought an alternative to the nation-state in the aftermath of the first world, for they believed that the political structure of the Dual Monarchy could be used to construct a new post-imperial political framework.

The notion of Central Europe/Mitteleuropa had considerable appeal to civil society intellectuals (such as Michnik, Konrad, Havel) in Poland, Hungary and Czechoslovakia in the 1980s. Kundera's famous 1984 essay “The Tragedy of Central Europe”, although written in exile, captured the mood of the period with his notion of a "return to Europe" and thus signalled an anti-communist appeal to the European traditions of the region. In the 1989 discourse on Mitteleuropa Russia is the Other. It was a contrast, too, to the western triumphalist narrative of the "end of history" and instead called for the "re-birth of Europe". In this use of the term, modernity as a societal condition is most evident, for by Europe is signalled the political assertion of the autonomy of civil society against the absolute state and the suppression of individual and collective liberty. Viewed in such terms, Mitteleuropa is not just a civilizational milieu, but reflects a model of modernity in which the 
conflict between civil society and the state has been central to its identity. It is possibly this post-socialist conception of Mitteleuropa that has the most relevance for the present day; it offers a way to re-address the question of the inter-cultural and multi-national legacy of a poly-centric region whose borders have continued to change.

\section{East Central Europe}

In recent years the notion of East Central Europe has emerged less as an alternative to the idea of Central Europe than a demarcation within it of a more narrowly defined region [see Arnason 2005a; Arnason and Doyle 2010; Troebst 2003]. Unlike the broader category of Central Europe it does not have the same resonance in terms of an identity and has been mostly used by historians of the region, such as Szücs [1988] and Halecki [1950, 1953], who noted an inner dualism within Central Europe between its western and eastern orientations. Yet a case can be made for its relevance as a distinctive historical heritage. While Central Europe refers to a wider area that includes the German speaking world and much of the Habsburg territories, the notion of East Central Europe pertains specifically to Poland, Hungary, the former Czechoslovakia. The notion should be extended to include Slovenia, which can also be regarded as part of Central Europe's eastern face. However, the core has generally been taken to be Hungary, the Czech lands, and Poland. The notion of East Central Europe in many ways approximates to the non-Austro-German Mitteleuropa, and a contrast to what might be more accurately termed West Central Europe. As a region, it is located between the Baltic and the Adriatic, on the one side, and on the other between Russia to the East, the Ottoman Empire to the South East and the various incarnations of the German empires in West. For this reason, it accords most precisely with the idea of "the lands in between". The region is thus to be distinguished from the Ottoman influenced South Eastern Europe and from North Eastern Europe, in the sense of the western Russian speaking world and the Baltic region (see below). Szücs, in his classic essay written in 1981, argued it lay between two areas of expansion: the western zone of expansion and the Russian one to the East [Szücs 1988: 313].

In civilizational terms, East Central Europe is a product of western Christianity, but represents the interface of the Carolingian tradition with Slavic, Hungarian, and eastern influences. Its identity was shaped against the Ottomans to the South East and the Russians to the East. As Arnason [2005a: 392] has argued, its heritage is more intra-civilizational than inter-civilizational, since the dominant influences were variants of Western Christianity. However, the inter-civilizational dimension is also present in view of the older conflict in the region between Western and Eastern Christianity before the final alignment with the western tradition in the ninth century. Before the formation of the Polish, Bohemian and Hungarian kingdoms, the area saw the emergence of the Christian principality of Moravia, destroyed by the Magyar invasion around 900, and later the other Czech kingdom to the west, namely Bohemia. The three kingdoms that consolidated in the region and shaped its identity as a historical region were themselves expansionist. Of the three kingdoms, though all integrated into western Christianity, the Bohemian kingdom was more closely integrated into the western tradition, being part of, and for a time, home to the capital of the Holy Roman Empire. Due to the Hussite movement, it has a good claim to be seen as the beginning of the Reformation, and the conflict between the Hussites and 
a Catholic Church attempting to reform itself prefigured the later battle between the Reformation and the Counter-Reformation. There is another sense in which the region can be considered to be an important area of inter-civilizational influences. In the three core areas, Bohemia, Poland and Hungary there has been for a long a large Jewish population that was fully integrated into the social, cultural and economic life of the societies. The Jewish dimension of the region, by far the most important in all of Europe, added to its multi-ethnic diversity. The loss of this after the Shoah represents a major cultural loss for the region and for Europe.

While Hungary and the Czech nation remained relatively intact in their borders over the centuries, the case of Poland is rather more complicated. Its borders have shifted many times in history and, as with much of central Europe, it has had a divided heritage between its eastern and western orientations. Of these it is undoubtedly the western pull that has been decisive and led to the creation by the Jagellonian dynasty of the Polish-Lithuanian kingdom in the sixteenth century. Stretching from the Baltic to the Black Sea, this was a powerful and large multi-national state that was created in 1385 when the Jagellonian dynasty came to the Polish crown, consolidated into a closer union in 1569 and lasted until its demise in 1795 following the partition of Poland. This episode is also an illustration of the involvement of the region in a wider borderland area. The Lithuanian link did not endure, though arguably a case could be made for the inclusion of Lithuania and the Baltic states in the category of East Central Europe. However, their different historical paths and later patterns of state formation and societal modernization put them on a trajectory different from that of Poland, Hungary and the Czech Republic, a region that can be extended to include both Slovakia and Slovenia.

An example of the civilizational current in the region, pan-Slavism was for a time a reflection of a transnational identity that tied the region to a broader trans-region. Although it did not endure, due not least to the diverse Slavic traditions, significant cultural differences between the Russian and Polish Slavophiles, and the different routes that the Slavic peoples had embarked on, it illustrates a departure from the wider Central European region. The eastern versus the western faces of the regions were less strong in the Czech lands and in Hungary, while in Poland the search for a Slavic nativism based on a peasant culture ceased to be significant by the twentieth century and in all parts of the region a pronounced European consciousness was present and, especially in the Czech case, an integral part of its national identity.

From the perspective of modernity, the core countries of East Central Europe can all be seen as within the broader category of European modernity. Their historical experience has been marked by resistance to absolutism. In the early modern period, especially in the Poland and in Bohemia, but also in Hungary, there was considerable resistance to absolutism, in the case of Bohemia resistance to the Habsburgs and in the case of Poland to the Russian empire. Within their territories absolute rule was curbed by traditions of rights and privileges of the nobles that set limits to imperial power without representation and eventually provided the ground on which nationalism would rise. This has been described as a political culture of government by estates and differs from western monarchical and absolutist rule as well as from Muscovite autocracy and Ottoman centralized statehood [Müller 2010: 115]. This tradition gave to the region a political heritage that can be seen as basis of a democratic tradition, albeit a weak one. Unlike, other parts of 
what was once called Eastern Europe, such as Romania and Bulgaria, the area shared with the west a similar history based on feudalism and private ownership, though the transition to industrialization took place much later [Berend 2005: 402]. Western influences were stronger than in the areas further east, to the south in the Balkans and to the north where Russia exerted more influence. Despite these similarities, nation-state building since 1919 put the region on a different course from the mainstream North Western and Mediterranean regions, for in this region the problem of linguistic, ethnic and cultural plurality were very great and not easily accommodated into the mono-cultural design of the national state.

In the twentieth century, East Central Europe was massively transformed by the double impact of German fascism from the west and from the east by communism and Soviet occupation. This experience ensured that modernity would take a different form in the region, which also experienced an experiment with state formation. The creation in 1918 of Czechoslovakia can be seen as a variant of modernity that eventually proved too fragile to last and the two nations finally separated in 1992 [Arnason 2005b]. Though it should be noted that in all of the Soviet bloc in central and eastern Europe, it was in the previously more European and western oriented Czechoslovakia that communism received considerable domestic support. Some of the most significant debates on the meaning of democracy and civil society took place in the countries of East Central Europe in the second half of the twentieth century [see Garton Ash 1993]. The assertion of civil society by dissident intellectuals against the totalitarian state has been a significant aspect of European political modernity that had a transformative impact in the region leading to the eventual collapse of Soviet domination.

\section{South Eastern Europe}

As a historical region South Eastern Europe presents a number of difficulties of definition, being in part an extension of both Eastern and Central Europe. However, the specificity of the region marks it off from both in very distinctive ways. The region in question concerns the Balkans including Bulgaria, Macedonia, Albania, Greece and Romania. The latter two, especially Greece, are by no means self-evident. The case for the inclusion of Greece within the category of South Eastern Europe is made on the basis of its participation in the Byzantine-Orthodox civilizational background, which has been arguably more significant for its history than its entry to the western world since its independence from the Ottoman Empire in the early nineteenth century. Moreover, in the course of that century Greek culture had a formative impact on the rest of the Balkans. As argued earlier, Greece can also be considered as part of Mediterranean Europe. However, in consideration of the overall historical, civilizational and geopolitical context, Greece can be seen as part of South Eastern Europe, as can Romania. Since Romania was formed in 1859 out of the historical region of Moldova, along with Wallachia, the present state of Moldova can be located with the wider region of South Eastern Europe. As a historical region, South Eastern Europe while not being entirely reducible to the Balkans is unavoidably more or less synonymous with it, thus giving to the area a certain identity.

From a civilizational perspective the region is defined by two orientations. Firstly, the Byzantine and Orthodox heritage has been an important civilizational influence. The entire 
Balkan region differs from the other regions of Europe by the Orthodox faith. Orthodoxy, deriving from the Byzantine tradition, has also remained an enduring feature of Bulgaria and Romania [Blokker 2010]. The second civilizational influence is the Ottoman-Islamic heritage. Since the Ottoman conquests of the Bulgarian and Serbian kingdoms, the region underwent a very different history to that of the rest of Europe. Due to the nature of Ottoman rule, Islam was not imposed on the populations of the conquered countries, but Islamic influences were present and in many cases there were conversions to Islam, examples being Albania and Kosovo. More important than Islam was the wider Ottoman influence in the region. In European historiography the area was once referred to as Turkey-in-Europe and was the object of much western, especially British, Prussian and Habsburg, foreign policy making in the nineteenth century [Müller 2001]. In addition to these factors, the Slavic component has been significant, uniting at least linguistically the Croats, Bosnians, Bulgarians, Macedonians, Montenegrins, Serbs, and Slovenes. Yugoslavia - meaning "the land of the Southern Slavs" - derived its name from this civilizational unity. The link between the Slavophile movement and orthodoxy adds an additional layer of weight to the civilizational specificity of the region and has often been regarded as a basis for anti-westernism. Many Bulgarians and Serbs, influenced more by Russian than Greek culture, saw Europe as a distinct cultural form different from the Byzantine legacy of Slavdom and Orthodoxy [Mishkova 2008: 245].

As a geopolitical and civilizational space South Eastern Europe can be seen for much of its history located between the Habsburg and Ottoman Empires. In the case of Bulgaria, the Russian influences were significant, although in this instance to be explained less by the direct impact of Russia than by appropriation by the Bulgarian intelligentsia of Russian culture in order to combat the dominance of Greek cultural superiority in the Balkan region [Mishkova 2008: 242]. In the second half of the twentieth century the area, along with much of central and southern Europe other than Greece, fell under Russian domination. The Russian and Ottoman moments, in particular the latter, shaped the region in ways that mark it off from the rest of Europe. These amount to a civilizational influence and attest to the presence within Europe of neighbouring civilizations, which give to the European heritage its character as a constellation of interacting civilizations.

Europe has been greatly shaped by the seas that surround it. This is especially true of South Eastern Europe. The Black Sea is as important, if not more, than the Mediterranean and the Adriatic seas in the region. Its place and significance in European history has been neglected. The Balkan region is generally seen as a mountainous region - the name Balkan means mountains - and one that is cut off from the rest of Europe. Placing the Black Sea rather than landmasses at the centre of stage gives a rather different view of the region. As Neal Ascherson [1995] has argued in his travel history of the Black Sea, over many centuries the Black Sea united cities and regions in Greece, the Ukraine, Turkey, Bulgaria and Romania. In this perspective the Black Sea is, like the Mediterranean Sea, a zone of interconnections between Europe and its neighbouring regions. The Black Sea, which receives five rivers including the Danube and the Don, has been important in European history since antiquity. The Crimea was one of the most important centres of the trading networks in the Greek world and it was especially important for Classical Athens; it was the site of a major war in the nineteenth century and the location of the Yalta conference, which symbolically represented the post-war division 
of Europe between East and West [Ascherson 1995: 10; Feher 1987]. Such a view of South Eastern of Europe would place it in relation to the Caucasus area, in particular linked to Georgia and Armenia. Instead of seeing the area as cut off, as in mainstream Eurocentric accounts, it should be seen as constituting links between the different cities and regions drawn together by the Black Sea. In this view, William McNeill [1964] locates the region as part of a wider Danubian and Pontic European region and constituting what he termed Europe's “Steppe Frontier”.

Any discussion of the modernity of the South Eastern of Europe is unavoidably complicated by the perceived view of backwardness with respect to western Europe and a representation of the region in terms of "Balkanism", which Todorova [1997] regards as another kind of Orientalism. Representations of especially the Balkan area as the opposite to the West and as an extension of the Ottoman East have also been reflected in the ways the Balkans have also perceived themselves. Such positions operate on the basis of a distinction of core and periphery where by the periphery is always defined in relation to the modernity and high civilization of the core. This fails to capture the diversity of Europe and its multiple civilizational logics. By reducing the Balkan region to an extension of the Ottoman East, it also fails to understand how a different route to modernity is possible. This eurocentric tendency should not be exaggerated, for it would appear that it was more recent than previously thought [Mishkova 2008]. Larry Wolff [1994], for instance, claimed this hegemonic discourse was part of the eighteenth century Enlightenment, but it may have been a later nineteenth development. As Mishkova [Mishkova 2008: 251] has argued, while the "gaze of the Other" was always a feature of the Balkans, in reality there existed many gazes often in conflict with each other.

\section{North Eastern Europe}

Any account of the historical regions of Europe is complicated by the question of what constitutes Eastern Europe or the East of Europe today in light of the absence of any clear lines of demarcation. All such designations are relative - the northern tip of Norway is as geographically east as Istanbul - and generally based on the assumption that the core is the west. The Cold War division of Europe has left a lasting mark on the face of Europe, but in the longer perspective of history the division it created between an East and West needs to be differentiated. However getting entirely rid of the notion of an Eastern Europe is also fraught with difficulties. There is a sense in which as a consequence of the developments that have occurred since 1990 that Eastern Europe should now be projected further to the east and refers to the western regions of the Russian speaking lands. In this view, Eastern Europe refers to Belarus, Kalingrad, Ukraine, and Moldova.

The approach taken in this paper is to define the eastern component of Europe by a logic that configures the mental map in terms of East Central, South East and a North East. According to this reasoning, Eastern Europe is best seen in terms of three interrelated zones. Of these the latter is the more complicated one; instead of being termed Eastern Europe - or even "far eastern Europe" or some such formulation - the term North Eastern Europe is the more accurate one. The area comprising it includes the Baltic Republics in addition to Kalingrad, Belarus, Ukraine, and possibly Moldova. While North Western 
Europe would then extend inland into the vastness of Ukraine, as a region the area is centrally defined by its relation to the Baltic Sea which gives it its European character as a borderland area of interconnected cities.

These areas are clearly primarily influenced by Russia and were for a long time part of the Soviet Union [Szporluk 1991]. The three Baltic Republics, forcibly incorporated in 1940, have always been part of the wider European area and cities such as Tallinn and Riga were important Hanseatic cities and where German was widely spoken. Unlike other parts of the region, they are also part of western Christianity, Lithuania being predominantly Catholic and also the most northern Catholic nation. Kaliningrad was the former German city and province of Königsberg in East Prussia. Moldavia, which was partially colonized by the Romans, was considerably influenced by Romania, the modern state of which was formed in part of western Moldova. In the case of Moldova, North Western Europe merges into South Western Europe.

Belarus and Ukraine are clearly only partially European and the latter does not entirely fit into the designation North Eastern, which as used in this paper is partly as an alternative to the notion Eastern Europe (which is perhaps a more pertinent in the case of the Ukraine). However, both have strong European civilizational influences. Polish influences in Ukraine and Belarus have been historically strong, and of course Lithuania was part of the Polish-Lithuanian Kingdom. Parts of Poland were incorporated into Belarus after 1945. Western Ukraine has traditionally been regarded as European and was the least Soviet area in the USSR [Szporluk 1991: 475]. Russian and Ukraine historiography has traditionally distinguished both Belarus and the Ukraine from the general course of Russian history and have emphasized its Europeanness [Halecki 1950: 137]. However, there can be little doubt that the Ukraine in general is more closely allied with Russia than with Europe, for Kiev was the common birthplace of both Russian and the Ukraine. The trajectory of Russian history begins with the Kiev Rus before the foundation of Muscovite state which became the successor of the Kievan kingdom. Due to the overlapping and entangled histories of the area, there is then a good case to include these countries in the mapping of the historical regions of Europe.

In sum, in civilizational terms North Eastern Europe has been shaped by the Russian influence and to varying degrees by other civilizational currents. As a historical region it possibly has the weakest identity as a region, given the divisions of its history and the forcible incorporation of its territories into the Soviet Union. The Baltic republics themselves do not have a clearly articulated collective identity as a region; each having quite different histories prior to their incorporation into the Soviet Republic. The model of modernity in the region has been equally fragmented, depending on the degree of Russification. Of the historical regions of Europe it is the one that, with the exception of the Baltic republics, had the weakest civil society tradition and where democratization developed only relatively lately and incompletely. Again, with the exception of the Baltic Republics, where the modern market society was relatively advanced prior to their incorporation into the Soviet Union, virtually all these countries experienced a very late transition to capitalism. As a result the model of modernity that evolved there was shaped more by a feudal legacy - a term to be sure that can be used only with some difficulty in the Russian context - left by German, Nordic and Russian conquerors, and the subsequent rise of Soviet totalitarianism. 


\section{Conclusion}

The six historical regions discussed in this paper are historically variable and overlapping. They do not simply overlap with each other, but are also closely linked spatially and culturally with areas that lie outside the European region as a whole. The paper has stressed in this regard the formative influence of the east in the west, and the importance of the Russian and Ottoman-Islamic worlds in the making of Europe. This serves in part to correct the older eurocentric view of the making of Europe that tended to see Europe as shaped by itself and to define all its regions in terms of their relation to the North West. In approaching the question of the historical regions of Europe from such an inter-civilizational perspective, it may be possible to avoid an account that sees unity only as possible in face of a common enemy, for as we have seen there was neither one enemy that predominated nor was there a single core that gave to Europe its identity. To the extent to which it is possible to speak of the "idea of Europe", this must be found in the plurality of its regions, which offer an alternative to accounts of European history in terms of national narratives. The emphasis on a plurality of regions with their own civilizational backgrounds and routes to modernity does not, it must be noted, mean that there is no unity since all these regions interacted with each other and ultimately such interaction made possible the genesis of modernity and the formation of Europe as a world historical region.

\section{References}

Arnason, Johann P. (ed.). [2005a]. East Central European Perspectives. Special Issue of the European Journal of Social Theory 8 (4), pp. 387-400.

Arnason, Johann P. [2005b]. Alternating Modernities: The Case of Czechoslovakia. European Journal of Social Theory 8 (4), pp. 435-51.

Arnason, Johann P. and Doyle, Natalie (eds). [2010]. Domains and Divisions of European History. Liverpool: University of Liverpool Press.

Arnason, Johann P. - Wittrock, Bjorn (eds). [2012]. Nordic Paths to Modernity. Oxford: Berghahn Books.

Ascherson, Neal. [1995]. Black Sea: The Birth Place of Civilization and Barbarism. London: Cape.

Balibar, Étienne. [2003]. We are the Europeans: Reflections of Transnational Politics. Princeton: Princeton University Press.

Berend, Ivan T. [2005]. What is Central and Eastern Europe? European Journal of Social Theory 8 (4), pp. 401-16.

Chambers, Iain. [2008]. The Mediterranean Crossings: Politics of an Interrupted Modernity. Durham, NC: Duke University Press.

Delanty, Gerard. [2003]. The Making of a Post-Western Europe: A Civilizational Analysis. Thesis Eleven 72, pp. 8-24.

Featherstone, Kevin - Kazamias, George (eds). [2001]. Europeanization and the Southern Periphery. London: Frank Cass.

Garton Ash, Timothy. [1993]. The Magic Lantern: The Revolutions of '89 Witnessed in Warsaw, Berlin, and Prague. London: Vintage.

Feher, Ferenc. [1987]. Eastern Europe's Long Revolution against Yalta. East European Politics and Societies 2 (1), pp. 1-34.

Halecki, Oscar. [1950]. The Limits and Divisions of European History. New York: Sheed and Ward.

Halecki, Oscar. [1953]. Borderlands of Western Civilization: A History of East Central Europe. New York: Ronald Press.

McNeill, William H. [1964]. Europe's Steppe Frontier. Chicago: University of Chicago Press. 
Mishkova, Diana. [2008]. Symbolic Geographies and Vision of Identity: A Balkan Perspective. European Journal of Social Theory 11 (2), pp. 237-56.

Müller, Michael. [2010]. Where and When Was (East) Central Europe? In. Arnason, Johann P. - Doyle, Natalie (ed). Domains and Divisions of European History. Liverpool: University of Liverpool Press.

Müller, Michael. [2001]. Southern Europe as a Historical Meso-Region. European Review of History 10 (2), pp. 393-408.

Pace, Michelle. [2004]. The Politics of Regional Identity: Meddling with the Mediterranean. London: Routledge.

Pirenne, Henri. [2001]. Mohammed and Charlemagne. London: Dover.

Polayni, Karl. [1944]. The Great Transformation. New York: Rinehart.

Szücs, Jenö. [1988]. Three Historical Regions of Europe. In. Keane, J. (ed.) Civil Society and the State. London: Verso.

Szporluk, Roman. [1991]. The Soviet West - or Far Eastern Europe? East European Politics \& Societies 5 (3), pp. 466-82.

Todorova, Maria. [1997]. Imagining the Balkans. Oxford: Oxford University Press.

Vidmar-Horvat, Ksenija. - Delanty, Gerard. [2005]. Mitteleuropa and the European Heritage. European Journal of Social Theory 11 (2), pp. 203-18.

Wolff, Larry. [1994]. Inventing Eastern Europe: The Map of Civilization on the Mind of the Enlightenment. Stanford: Stanford University Press.

Gerard Delanty is Professor of Sociology and Social \& Political Thought, University of Sussex, UK. His most recent publications are Community (2nd edition) Routledge, 2010, The Cosmopolitan Imagination: The Renewal of Critical Social Theory, Cambridge University Press, 2009. He has edited (with Stephen P Turner) The International Handbook of Contemporary Social and Political Theory, Routledge 2011 and the Handbook of Cosmopolitan Studies, Routledge 2012. Recent journal articles have appeared in the British Journal of Sociology (2011), The Irish Journal of Sociology (2010), The Sociological Review (2012). 